\title{
Perbedaan Hasil Belajar Matematika Siswa Berdasarkan Tingkat Pendidikan Ayah
}

\author{
Fitri Yana ${ }^{1 *}$, Haida Fitri ${ }^{2}$ \\ Institut Agama Islam Negeri (IAIN) Bukittinggi, Kabupaten Agam, Indonesia \\ ${ }^{*}$ Corresponding Author
}

\begin{tabular}{l} 
Informasi Artikel \\
\hline Diterima Redaksi: 03 November 2021 \\
Revisi Akhir: 00 Maret 2021 \\
Diterbitkan Online: 00 Juni 2021 \\
Kata Kunci \\
\hline Tingkat pendidikan \\
Ayah \\
Hasil belajar \\
Matematika \\
Korespondensi \\
\hline E-mail: fyana050@gmail.com
\end{tabular}

\author{
A B S T R A C T
}

The background in this study is based on the observations of researchers at SMA Negeri 1 Merangin, based on the data on the educational level of fathers of class XI MIPA students who are very diverse where the percentages for elementary school/equivalent are 7.79\%, junior high school/equivalent 12.98\%, high school/equivalent $56.49 \%$ and the tertiary level $22.72 \%$. However, with the father's education level still elementary/equivalent and junior high/equivalent, this does not make the student's mathematics learning outcomes low either. This study aims to determine the difference in the level of father's education on the students' mathematics learning outcomes carried out at SMA Negeri 1 Merangin. This study is a population study using ex-post facto research methods. The total population in this study amounted to 154 students. Data collection techniques using documentation. Based on the results of the study using the Oneway Anova test, the significance value of students' mathematics learning outcomes was sig $=0.808$, at a significance level of $=0.05$. Because the value of sig $=0.808>=0.05 \mathrm{so} \mathrm{HO}$ is accepted. It can be concluded that there is no difference in students' mathematics learning outcomes based on the father's education level in the elementary, middle and high categories in class XIMIPA at SMA Negeri 1 Merangin.

Latar belakang pada penelitian ini didasari oleh hasil observasi peneliti di SMA Negeri 1 Merangin, berdasarkan data tingkat pendidikan ayah siswa kelas XI MIPA sangat beragam dimana diperoleh pesentase untuk tingkat SD/sederejat sebesar $7.79 \%$, SMP/sederajat $12.98 \%$, SMA/sederajat $56.49 \%$ dan tingkat perguruan tinggi $22.72 \%$. Namun dengan masih adanya tingkat pendidikan ayah SD/sederajat dan SMP/sederajat, hal tersebut tidak menjadikan hasil belajar matematika siswa tersebut rendah pula. Penelitian ini bertujuan untuk mengetahui perbedan tingkat pendidikan ayah terhadap hasil belajar matematika siswa yang dilaksanakan di SMA Negeri 1 Merangin. Penelitian ini adalah penelitian populasi yang menggunakan metode penelitian ex-post facto. Jumlah populasi pada penelitian ini berjumlah 154 siswa. Teknik pengumpulan data menggunakan dokumentasi. Berdasarkan hasil penelitian menggunakan uji Oneway Anova diperoleh nilai signifikansi hasil belajar matematika siswa sebesar $s i g=0.808$, pada taraf signifikansi $\alpha=0.05$. Karena nilai sig $=0.808>\alpha=0.05$ sehingga $\mathrm{H}_{0}$ diterima. Hal ini dapat disimpulkan bahwa tidak ada perbedaan hasil belajar matematika siswa berdasarkan tingkat pendidikan ayah kategori dasar menengah dan tinggi di kelas XI MIPA SMA Negeri l Merangin.

2021 by the authors. Submitted for possible open access publication under the terms and conditions of the Creative Commons Attribution-ShareAlike 4.0 International License-(CC-BY-SA) (https://creativecommons.org/licenses/by-sa/4.0/)

\section{Pendahuluan}

Pendidikan memiliki peran penting dalam pembangunan Nasional karena pendidikan merupakan sarana strategis untuk meningkatkan kualitas suatu bangsa. Semakin banyak pemuda berpendidikan diharapkan dapat memberikan dampak positif dalam pembangunan nasional dalam menghadapi persaingan global. Pada dasarnya pendidikan merupakan kebutuhan yang wajib dipenuhi oleh manusia karena tujuan utama pendidikan adalah mengembangakan potensi yang ada pada diri seseorang [1]. Berdasarkan Kamus Besar Bahasa Indonesia, pendidikan dapat diartikan sebagai proses pengubahan sikap dan tata laku seseorang atau kelompok orang dalam usaha mendewasakan manusia melalui upaya pengajaran dan pelatihan; proses, cara dan perbuatan mendidik.

Keberhasilan suatu proses belajar mengajar biasanya dilihat dari perolehan hasil belajar setiap siswa. Siswa yang memiliki perhatian lebih terhadap suatu mata pelajaran tentunya akan mendapatkan hasil belajar yang memuaskan. Hasil belajar merupakan kemampuan peserta didik terhadap pengetahuan, keterampilan, sikap dan nilai-nilai yang diberikan kepadanya [2]. 
Hasil belajar dapat disebut juga prestasi belajar. Prestasi belajar adalah hasil belajar yang diperoleh dan tampak nyata pada setiap siswa berupa penambahan pengetahuan, timbulnya pengalaman baru dan perubahan tingkah laku [3]. Menurut Nana Sudjana, hasil belajar adalah kemampuan yang dimiliki siswa setelah ia menerima pengalaman belajarnya. Menurut Hamalik hasil belajar adalah sebagai bentuk terjadinya perubahan tingkah laku pada diri seseorang yang dapat diamati dan diukur bentuk pengetahuan, sikap dan keterampilan [4, p. 30].

Hasil belajar mencakup tiga aspek yaitu aspek kognitif, aspek efektif dan aspek psikomotor . Aspek/Ranah kognitif adalah ranah yang mencakup kegiatan mental (otak). Segala upaya yang mencangkup aktivitas otak adalah termasuk ranah kognitif, Aspek/Ranah afektif yaitu menyangkut pada bidang sikap, Aspek/Ranah psikomotorik yaitu menekankan pada keterampilan skill [5, p. 71]. Pada penelitian ini akan dititik beratkan pada penelitian pada aspek kognitif. Hasil belajar merupakan output akhir setelah terjadinya proses pembelajaran. Salah satu indikator kesuksesan belajar siswa di sekolah adalah hasil belajar yang baik [6]. Hasil dan nilai belajar siswa tersebut dapat berupa angka, abjad dan lain sebagainya. Untuk mencapai hasil belajar yang baik bukan lah hal yang mudah, dalam hal ini pelajaran matematika. Masalah hasil belajar matematika yang rendah merupakan salah satu masalah dalam pendidikan Indonesia.

Metematika merupakan salah satu cabang ilmu pengetahuan yang memiliki peranan dalam perkembangan ilmu pengetahuan dan teknologi. Pada hakekatnya pembelajaran matematika berkenaan dengan konsep-konsep matematika yang tersusun secara hierarkis, terstruktur, logis dan sistematis mulai dari konsep yang paling sederhana sampai pada konsep yang paling kompleks. Menurut Vivi Saswita, Isnaniah, dkk matematika berfungsi sebagai alat, pola pikir, dan ilmu pengetahuan yang akan digunakan dalam kehidupan sehari-hari, dan bisa digunakan sebagai alat untuk memahami atau menampaikan suatu informasi [7]. Menurut James dan James yang dikutip oleh Erman Suherman pada tahun 2003 menjelaskan bahwa matematika adalah ilmu tentang logika mengenai bentuk, susunan, besaran, dan konsep-konsep yang berhubungan satu dengan yang lain dengan jumlah yang banyak yang terbagi ke dalam tiga bidang yaitu aljabar, analisis dan geometri [8, p. 19]. Sri Hastuti pada tahun 2017 dalam bukunya membagi definisi matematika sebagai ilmu deduktif, ilmu terstrusktur, ratu dan pelayan ilmu, matematika adalah ilmu tentang pola dan hubungan, dan matematika adalah bahasa simbol [9, p. 3].

Banyak hal yang mempengaruhi hasil belajar, seperti yang dikemukakan oleh Muhibbin syah yang menjelaskan bahwa faktor-faktor yang mempengaruhi hasil belajar sebagai berikut. (a) Faktor internal (faktor dari dalam diri siswa), yakni keadaan/kondisi jasamani dan rohani siswa. Faktor ini meliputi beberapa aspek, yaitu: aspek fisiologis (yang bersifat jasmaniah) seperti organ-organ khusus siswa contohnya tingkat kesehatan mata dan telinga yang sangat berpengaruh dalam kualitas informasi dan pengetahuan yang diperoleh siswa di kelas. Serta aspek psikologis (yang bersifat rohaniah) seperti intelegensi, sikap, bakat dan motivasi. (b) Faktor eksternal (faktor dari luar siswa), yakni kondisi lingkungan disekitar siswa. Faktor ini meliputi lingkungan sosial, seperti keluarga, guru, masyarakat, dan teman, serta lingkungan non sosial, seperti rumah, sekolah, peralatan, dan alam. (3) Faktor pendekatan belajar yakni jenis upaya belajar siswa yang meliputi strategi dan metode yang digunakan siswa untuk melakukan kegiatan pembelajaran materi-materi pelajaran. Faktor ini meliputi pendekatan tinggi, seperti speculative, achieving; pendekatan sedang, seperti analytical, deep; pendekatan rendah, seperti reproductive, surface [10, pp. 145-147].

Faktor-faktor tersebut saling berkaitan dan mempengaruhi satu sama lain. Seorang siswa yang bersikap conserving terhadap ilmu pengetahuan atau bermotif ekstrinsik (faktor eksternal), biasanya cenderung mengambil pendekatan belajar yang sederhana dan tidak mendalam. Sebaliknya, seorang siswa yang berinteligensi tinggi (faktor internal) dan mendapat dorongan positif dari orangtuanya (faktor eksternal), mungkin akan memilih pendekatan belajar yang lebih mementingkan kualitas hasil belajar. 
Jadi, karena pengaruh faktor-faktor tersebut diataslah muncul siswa-siswa yang berprestasi tinggi dan berprestasi rendah atau gagal sama sekali. Kompri menjelaskan prestasi belajar yang dicapai siswa dipengaruhi oleh dua factor utama yaitu faktor dari dalam diri siswa itu dan faktor yang datang dari luar diri siswa atau lingkungan. Faktor-faktor tersebut berupa kemampuan intelektual, kemampuan fisik, latar belakang keluarga, kebiasaan dan pendekatan belajar [3].

Orangtua memiliki peranan yang sangat vital terhadap pendidikan anak. Melalui orangtua lah anak-anak mulai berkenalan dengan lingkungan dan mengetahui hal-hal baru dalam kehidupan. Setiap orangtua pasti memilki keinginan untuk anak-anaknya tumbuh dan berkembang menjadi anak yang berprestasi. Orangtua yang memiliki tingkat pendidikan yang tinggi tentunya memiliki wawasan yang luas terhadap pendidikan dan akan berpengaruh terhadap gaya kepemimpinan keluarganya [11]. Ayah sebagai pemimpin dalam keluarga memiliki perananan penting dalam pendidikan anak. Hal ini sesuai dengan teori yang dikemukan oleh Slameto pada tahun 2003 yang menjelaskan peranan ayah dalam pendidikan anak adalah sebagai provider, teacher dan problem solver [3]. Hal ini sejalan dengan pendapat dari Clarke Stewart yang menjelaskan bahwa perlakuan ayah terhadap anak sangat berpengaruh terhadap intelektual anak [5]. Menurut Zahar Idris tingkat pendidikan seseorang erat kaitannya dengan tingkat pengembangan potensi fisik, emosional, social, moral, pengetahuan dan keterampilan [12, p. 45].

Teori-teori tersebut juga didukung oleh John Simmons dan Leigh Alexander pada tahun 1983, latar belakang keluarga berpengaruh terhadap hasil belajar anak. Latar belakang keluarga ini biasanya berkaitan dengan status sosial ekonomi keluarga. Dimana status sosial ekonomi menggunakan indicator pendidikan keluarga serta pekerjaan dan penghasilan orangtua [5]. Berdasarkan penjelasan teori dari para ahli di atas dapat disimpulkan bahwa orangtua (ayah) memiliki pengaruh terhadap hasil belajar siswa dalam hal ini tingkat pendidikan. Orangtua yang berpendidikan akan memiliki wawasan mengenai pendidikan jauh lebih luas dibandingkan orangtua yang memiliki pendidikan yang rendah, sehingga dapat membimbing dan mengarahkan anaknya untuk tekun belajar dan akhirnya memperoleh hasil belajar yang baik.

Dalam Kamus Umum Bahasa Indonesia, tingkat pendidikan adalah jenjang pendidikan yang dialami dalam suatu lembaga formal maupun informal. Tingkat Pendidikan formal adalah tingkat pendidikan yang berlangsung secara teratur, bertingkat dan mengikuti syarat-syarat tertentu secara ketat. Tingkat pendidikan formal dibagi menjadi tiga bagian yaitu tingkat pendidikan dasar, tingkat pendidikan menengah, dan tingkat pendidikan tinggi [13]. Berdasarkan UU No. 20 Tahun 2003 pasal 17 tentang sistem pendidikan menyatakan bahwa tingkat pendidikan dasar merupakan tingkat pendidikan yang melandasi pendidikan menengah. Satuan pendidikan terdiri atas satuan pendidikan formal yaitu, TK, SD dan sederajat, SMP dan sederajat, dan SMK dan sederajat, perguruan tinggi, dan satuan pendidikan non formal yaitu PAUD, PKBM dan LKP. Pernyataan tersebut sejalan pula dengan bunyi UU No. 20 tahun 2003 BAB I pasal 1 ayat 8 yaitu:Jenjang pendidikan merupakan tingkatan pendidikan yang dikukuhkan berlandaskan level perkembanagan siswa, tujuan yang harus diraih, dan keterampilan yang dikembangkan yang mana pendidikan indonesia pada jenjang pendidikan formal terdiri dari usia dini, dasar, menengah dan tinggi. Jadi dapat disimpulkan bahwa Tingkat pendidikan orangtua adalah tingkat pendidikan yang telah ditempuh oleh orangtua, melalui pendidikan formal di sekolah dari tingkat paling rendah hingga tingkat paling tinggi yaitu, sd, smp, sma hingga perguruan tinggi.

Berdasarkan observasi peneliti, pendidikan orangtua siswa SMA Negeri 1 Merangin sangat beragam, mulai dari tingkat pendidikan sekolah dasar, sekolah menengah pertama, sekolah menengah atas hingga tingkat perguruan tinggi. Melihat bahwa tingkat pendidikan orangtua termasuk aspek eksternal yang memiliki pengaruh terhadap hasil belajar. Maka perlunya perhatian khusus untuk latar belakang keluarga siswa, mengingat bahwa matematika 
dianggap sulit oleh sisiwa, sehingga memerlukan bimbingan dan arahan khusus dalam memahami pelajaran dan mengerjakan latihan soal-soal dirumah. Hal lain penulis dapati dari observasi awal pada tanggal 8 April 2021 yaitu hasil UTS siswa masih terbilang rendah dan bervariasi,berdasarkan data yang diperoleh terdapat nilai siswa yang rendah berasal dari keluarga dengan tingkat pendidikan orangtua kategori rendah yaitu SD ataupun SMP saja. Namun juga diperoleh nilai belajar siswa yang rendah namun memiliki orangtua yang berpendidikan tinggi.

Hal tersebut lah yang membuat penulis tertarik meneliti lebih lanjut apakah terdapat perbedaan hasil belajar matematika siswa berdasarkan tingkat pendidikan ayah. Maka dari itu penulis mengambil judul penelitian "Perbedaan Hasil Belajar Matematika Siswa berdasarkan Tingkat Pendidikan Ayah di Kelas XI MIPA SMA Negeri 1 Merangin"

\section{Metode Penelitian}

Penelitian ini merupakan penelitian ex-post facto dimana peneliti ingin melihat apakah terdapat perbedaan hasil belajar matematika siswa berdasarkan tingkat pendidikan ayah di kelas XI MIPA SMA Negeri 1 Merangin. Penelitian ini juga merupakan penelitian populasi dengan populasi seluruh siswa kelas XI MIPA SMA Negeri 1 Merangin Tahun Pelajaran 2020/2021 sebanyak 154 siswa. Pada penelitian ini teknik pengumpulan data menggunakan dokumentasi dan teknik analis data yang digunakan adalah analisis variansi satu jalan atau one way. Tipe data yang digunakan pada penelitian yang menggunakan uji oneway anova adalah tipe data ordinal. Data ordinal adalah data yang berasal dari suatu objek atau kategori yang telah disusun secara berjenjang menurut besarnya. Setiap data ordinal memiliki tingkatan tertentu yang dapat diurutkan mulai dari terendah sampai tertinggi atau sebaliknya. Data ordinal yang dimaksud pada penelitian ini adalah tingkat pendidikan orangtua yang mana tingkat pendidikan orang tua tersebut dikategorikan menjadi tiga kelompok yaitu tingkat pendidikan orangtua kategori dasar, tingkat pendidikan orangtua kategori menengah dan tingkat pendidikan orangtua kategori tinggi. Pengkategorian tersebut dibuat berlandaskan UU No. 20 tahun 2003 BAB I pasal 1 ayat 8. Analisis variansi adalah teknik analisis untuk mengetahui apakah terdapat perbedaan yang signifikan antara rata-rata beberapa kelompok populasi (lebih dari dua), melalui ukuran-ukuran penyebaran dari masing-masing kelompok populasi. Sebelum melakukan uji anova satu arah maka perlu dilakukan uji normalitas sebaran dan homogenitas.

\subsection{Uji Normalitas}

Uji normalitas adalah uji yang dilakukan untuk menilai sebaran data pada sebuah kelompok data atau variabel berdistribusi normal atau tidak. Uji normalitas merupakan syarat awal yang harus dipenuhi dalam menguji hipotesis pada analisis variansi (Anova) satu arah. Data yang diuji normalitas pada penelitian ini adalah hasil belajar matematika siswa. Pengujian dilakukan menggunakan uji liliefors dengan taraf signifikasi a $=0.05$

\subsubsection{Menetapkan Hipotesis}

$\mathrm{H}_{0}$ : data siswa dengan tingkat pendidikan ayah kategori dasar berdistribusi normal

$\mathrm{H}_{1}$ : data siswa dengan tingkat pendidikan ayah kategori dasar tidak berdistribusi normal

$\mathrm{H}_{0}$ : data siswa dengan tingkat pendidikan ayah kategori menengah berdistribusi normal

$\mathrm{H}_{1}$ : data siswa dengan tingkat pendidikan ayah kategori menengah tidak berdistribusi normal

$\mathrm{H}_{0}$ : data siswa dengan tingkat pendidikan ayah kategori tinggi berdistribusi normal

$\mathrm{H}_{1}$ : data siswa dengan tingkat pendidikan ayah kategori tinggi tidak berdistribusi normal

2.1.2 Menyusun skor hasil belajar siswa dalam suatu tabel skor, disusun dari yang terkecil sampai yang terbesar. 
2.1.3 Pengamatan $\mathrm{x}_{1}, \mathrm{x}_{2}, \mathrm{x}_{\mathrm{a}, \ldots,}, \mathrm{x}_{\mathrm{n}}$ kemudian dijadikan bilangan baku $\mathrm{z}_{1}, \mathrm{z}_{2}, \mathrm{z}_{\mathrm{a}, \ldots,}, \mathrm{z}_{\mathrm{n}}$, dengan menggunakan rumus sebagai berikut.

$$
\mathrm{z}_{\mathrm{i}}=\frac{\mathrm{x}_{\mathrm{i}}-\mathrm{x}}{\mathrm{s}} \quad \begin{aligned}
& \text { Keterangan }: \\
& \\
& \quad
\end{aligned}
$$

2.1.4 Untuk tiap bilangan baku ini dengan menggunakan daftar distribusi normal baku, kemudian di hitung peluang:

$\mathrm{F}\left(\mathrm{z}_{\mathrm{i}}\right)=\mathrm{P}\left(\mathrm{z} \leq \mathrm{z}_{\mathrm{i}}\right)$

2.1.5 Menghitung proporsi $\mathrm{z}_{1}, \mathrm{z}_{2}, \mathrm{z}_{\mathrm{a}}, \ldots, \mathrm{z}_{\mathrm{n}}$, yang lebih kecil atau sama $\mathrm{z}_{\mathrm{i}}$, jika proporsi dinyatakan dengan $\mathrm{S}\left(\mathrm{z}_{\mathrm{i}}\right)$ dengan menggunakan rumus maka :

$$
\mathrm{S}\left(\mathrm{z}_{\mathrm{i}}\right)=\frac{\text { banyaknya } \mathrm{z}_{1} \mathrm{z}_{2} \mathrm{z}_{\mathrm{a}} \ldots \mathrm{z}_{\mathrm{n}} \text { yang } \leq \mathrm{z}_{\mathrm{i}}}{\mathrm{n}}
$$

2.1.6 Menghitung selisih $\mathrm{F}\left(\mathrm{z}_{\mathrm{i}}\right)-\mathrm{S}\left(\mathrm{z}_{\mathrm{i}}\right)$ kemudian tentukan harga mutlaknya.

2.1.7 Ambil harga mutlak yang terbesar dan harga mutlak selisih diberi simbol $\mathrm{L}_{0}$,

$$
\mathrm{L}_{0}=\operatorname{Maks}\left|\mathrm{F}\left(\mathrm{z}_{\mathrm{i}}\right)-\mathrm{s}\left(\mathrm{z}_{\mathrm{i}}\right)\right|
$$

2.1.8 Kemudian bandingkan nilai $\mathrm{L}_{0}$ dengan nilai $\mathrm{L}_{\text {tabel }}$ yang diperoleh dari daftar nilai kritis untuk uji Liliefors pada taraf $\alpha=0.05$

2.1.9 Kriteria pengujiannya :

Jika $\mathrm{L}_{0}<\mathrm{L}_{\text {tabel }}$ berarti data populasi berdistribusi normal.

Jika $\mathrm{L}_{0}>\mathrm{L}_{\mathrm{tabel}}$ berarti data populasi berdistribusi tidak normal [14, p. 446].

Pada uji normalitas juga dibantu dengan bantuan SPSS dengan kriteria pengujiannnya sebagai berikut. (a) Masuk ke program SPSS. (b) Isikan semua data pada kolom yang tersedia. (c) Simpan data yang telah kita input, dengan cara klik save file. (d) Klik variabel view pada SPSS data editor. (e) Pada kolom Name pertama klik "Nilai" dan kolom Name kedua ketik "Tingkat Pendidikan Ayah". (f) Pada kolom Type pilih "numeric". (g) Pada kolom Values baris kedua pada value ketik "1" dan pada tabel ketik "rendah" kemudian add, ketik "2" pada tebel ketik "sedang", dan terakhir ketik "3" pada tabel. (h) Pada kolom measure baris pertama klik nominal dan pada baris kedua klik skala ordinal. (i) Klik Analyze, arahkan kursor ke descriptive statistic dan dipilih explore. (j) Masukkan nilai ke dependent list dan kelas ke faktor list. (k) Klik plots dan klik normality plots with test, tekan continue dan OK.

Berdasarkan dari hasil test of normality diatas kriteria pengujian diambil berdasarkan nilai probalitas. Dengan taraf nyata $\alpha=0,05$ : Jika probalitas (sig) $\geq 0,05$, maka data berdistribusi normal. Jika

probalitas $(\mathrm{sig})<0,05$, maka data tidak berdistribusi normal.

\subsection{Uji Homogenitas}

Pada analisis statistic, uji homogenitas bertujuan untuk mengetahui apakah variasi dari beberapa data populasi memiliki variansi yang sama atau tidak. Uji homogenitas yang digunakan adalah metode Barlett. Uji Barlett diperlukan dalam beberapa uji statistic seperti Analysis of Variance (ANOVA) [15, p. 58]. Berikut langkah langakah uji barlett:

2.2.1 Hipotesis

$\mathrm{H}_{0}$ : sampel berasal dari populasi yang homogen

$\mathrm{H}_{1}$ : sampel tidak berasal dari populasi yang homogeny

2.2.2 Menyusun table kerja uji homogenitas

2.2.3 Menghitung variansi gabungan, B dan 


$$
\begin{aligned}
& S^{2}=\frac{\sum(n-1) s i^{2}}{\sum(n-1)} \\
& B=\left(\log S^{2}\right) \times \sum n i-1 \\
& X^{2}=2,303 \times\left\{B-(d k) \log s i^{2}\right\}
\end{aligned}
$$

Keterangan:

$\mathrm{S}^{2}=$ variansi gabungan

$\mathrm{Si}^{2}=$ variansi tiap sampel

$\mathrm{B}=$ harga satuan

$\mathrm{Ni}=$ jumlah sampel ke $\mathrm{i}$

2.2.4 Menghitung harga satuan Chi-kuadrat $\left(\mathrm{X}^{2}\right)$ dengan rumus :

$$
X^{2}=(\ln 10)\left\{B-\sum\left(n_{\mathrm{i}}-1\right) \log S_{i}^{2}\right\}
$$

2.2.5 Membandingkan $\mathrm{X}_{\text {hitung }}^{2}$ dengan $\mathrm{X}_{\text {tabel }}^{2}$ dengan kriteria bila $\mathrm{X}_{\text {hitung }}^{2}<\mathrm{X}_{\text {tabel }}^{2}$ untuk taraf $\alpha$ maka $\mathrm{H}_{0}$ diterima artinya populasi homogen. Dan apabila $\mathrm{X}_{\text {hitung }}^{2} \geq \mathrm{X}_{\text {tabel }}^{2}$ untuk taraf $\alpha$ maka $\mathrm{H}_{0}$ ditolak artinya populasi tidak homogen.[14]

Uji homogenitas juga dibantu dengan spss dengan langkah sebagai berikut: (a) Klik variable view, sekanjutnya adalah mengisi property variabel penelitian pada hasil belajar matematika dan tingkat pendidikan orangtua seperti nama, type, width, decimals, label, value, missing, colums, align, measure dan role. (b) Klik data view, lalu masukkan input data hasil belajar matematika untuk tingkat pendidikan kategori rendah, sedang dan tinggi ke kotak nilai. Kemudian masukkan data kategori atau kode untuk tingkat pendidikan kategori dasar (1), tingkat pendidikan kategori menengah (2), tingkat pendididkan kategori tinggi (3). (c) Dari menu SPSS, klik analyze dan pilih classify, lalu klik discriminant. (d) Akan muncul kotak dengan nama dialog. Selanjutnya masukkan variabel hasil belajar ke kolom independent dan masukkan variabel tingkat pendidikan orangtua ke groupig variabel. Lalu klik define range, kemudian angka mininimum 1 dan maksimum 3 dan klik continue, klik kotak statistik, maka akan muncul dialog box. (e) Klik kotak Box's M. (f) Klik ok untuk memproses data. (g) Menarik kesimpulan. Apabila nilai sig $>\alpha=0.05$, maka dapat disimpulkan data homogeny [16, pp. 185-190].

\subsection{Uji Hipotesis}

Setelah memenuhi berbagai uji prasyarat, kemudian dapat dilakukan uji hipotesis dengan menggunakan uji one way anova.

2.3.1 Membuat hipotesis penelitian $\mathrm{H}_{0}$ dan $\mathrm{H}_{1}$

$\mathrm{H}_{0}$ : tidak ada perbedaan hasil belajar matemtika siswa berdasarkan tingkat pendidikan ayah.

$\mathrm{H}_{1}$ : ada perbedaan hasil belajar matemtika siswa berdasarkan tingkat pendidikan ayah

2.3.2 Membuat hipotesis statistik

$\mu_{1}$ : tingkat pendidikan kategori dasar

$\mu_{2}$ : tingkat pendidikan kategori menengah

$\mu_{3}$ : tingkat pendidikan kategori tinggi

$\mathrm{H}_{0}: \mu_{1}=\mu_{2}=\mu_{3}$

$\mathrm{H}_{1}: \mu_{1} \neq \mu_{2} \neq \mu_{3}$

2.3.3. Menentukan taraf signifikansi

Berikut tabel ragam anova satu jalur:

Tabel 1. Tabel Ragam Anova Satu Jalur

\begin{tabular}{cccccc}
\hline SV & JK & DK & VAR & Fhitung & Ftabel \\
\hline $\begin{array}{c}\text { Antar } \\
\text { group A }\end{array}$ & $\left(\frac{\left(\sum \mathrm{x}_{1}\right)^{2}}{\mathrm{n}_{1}}+\frac{\left(\sum \mathrm{x}_{2}\right)^{2}}{\mathrm{n}_{2}}+\frac{\left(\sum \mathrm{x}_{\mathrm{g}}\right)^{2}}{\mathrm{n}_{\mathrm{g}}}\right)-\frac{\left(\sum \mathrm{x}_{\mathrm{T}}\right)^{2}}{\mathrm{n}_{\mathrm{T}}}$ & $\mathrm{A}-1$ & $\frac{\mathbb{J K}_{\mathrm{A}}}{\mathrm{DK}_{\mathrm{A}}}$ & $\frac{\operatorname{VAR}_{\mathrm{A}}}{\operatorname{VAR}_{\mathrm{d}}}$ & $\mathrm{A}$ \\
\hline $\begin{array}{c}\text { Dalam } \\
\text { grup }\end{array}$ & $\mathbb{J K}_{\mathrm{D}}=J_{\mathrm{T}}-J_{\mathrm{A}}$ & $\mathrm{N}-\mathrm{A}$ & $\frac{\mathbb{J K}_{\mathrm{D}}}{\mathrm{DK}_{\mathrm{D}}}$ & - & - \\
\hline Total & $\mathrm{JKt}$ & $\mathrm{N}-1$ & & \\
\hline
\end{tabular}


Kriteri pengujian hipotesis pada tahap keberartian $\alpha=0.05$, jika $F_{\text {hitung }} \geq \mathrm{F}_{\text {tabel }}$ maka $\mathrm{H}_{0}$ ditolak, dan jika $\mathrm{F}_{\text {hitung }}<\mathrm{F}_{\text {tabel }}$ maka $\mathrm{H}_{0}$ diterima [17]. Peneliti juga menggunakan alat bantu analisis SPSS untuk menguji hipotesis menggunakan uji one way anova dengan ketentuan kriteria. (a) Input data ke dalam SPSS. (b) Dari menu utama SPSS, pilih menu analyze, kemudian pilih submenu comparemeans, lalu pilih oneway anova. (c). Pada halaman "oneway anova", untuk dependent list diisi dengan variabel hasil belajar, dan faktor diisi dengan variabel tingkat pendidikan orangtua. (d) Klik options, dan descriptive. (e) Klik tombol post hoc, klik kolom LSD. (f) Kllik continue, dan klik ok. (g) Menarik kesimpulan. Jika nilai sig > 0.05. Hal ini berarti $\mathrm{H}_{0}$ diterima dan Jika nilai sig $<0.05$. Hal ini berarti $\mathrm{H}_{0}$ ditolak.

\title{
3 Hasil dan Pembahasan
}

Data hasil belajar matematika siswa diperoleh dari nilai asli ujian akhir semester genap siswa kelas XI MIPA SMA Negeri 1 Merangin. Dimana terdiri dari 154 siswa yang berasal dari 5 kelas dengan rata-rata jumlah kelas sebanyak 30 siswa.

Tabel 2. Jumlah Siswa Kelas XI MIPA SMA Negeri 1 Merangin Tahun Pelajaran 2020/2021

\begin{tabular}{ccc}
\hline No. & Kelas & Jumlah Populasi \\
\hline 1 & XI MIPA 1 & 32 \\
2 & XI MIPA 2 & 31 \\
3 & XI MIPA 3 & 28 \\
4 & XI MIPA 4 & 32 \\
5 & XI MIPA 5 & 31 \\
\hline & Jumlah & 154 \\
\hline
\end{tabular}

Tingkat pendidikan dikategorikan menjadi tiga kelompok yaitu tingkat pendidikan ayah kategori dasar, menengah dan tinggi. Tingkat pendidikan kategori dasar adalah SD/ sederajat dan SMP/sederajat, tingkat pendidikan kategori menengah adalah SMA, tingkat pendidikan kategori tinggi adalah D1, D2, D3, S1, S2 dan S3. Data tingkat pendidikan orangtua diperoleh dari data siswa yang ada di sekolah. Data tingkat pendidikan tersebut dapat dipersentasikan sebagai berikut:

\section{TINGKAT PENDIDIKAN AYAH SISWA KELAS XI MIPA SMA NEGERI 1 MERANGIN} $7.79 \%$

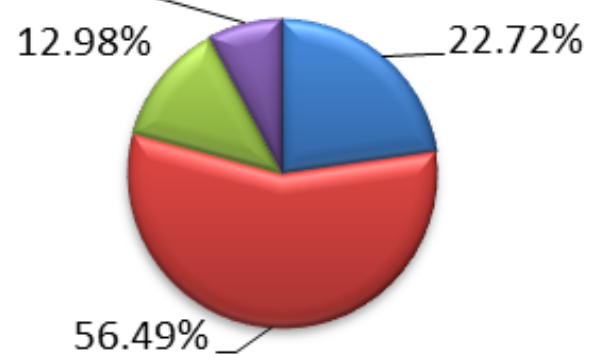

\author{
Q Perguruan Tinggi \\ 口SMA/ sederajat \\ $\square \mathrm{SMP} /$ sederajat \\ $\square \mathrm{SD} /$ sederajat
}

Gambar 1. Pie Chart Distribusi Frekuensi Tingkat Pendidikan Ayah Siswa 
Pada penelitian ini tingkat pendidikan ayah dikategorikan menjadi 3 kelompok yaitu tingkat pendidikan orangtua kategori dasar, tingkat pendidikan orangtua kategori menengah dan tingkat pendidikan orangtua kategori tinggi. Data hasil belajar matematika siswa berdasarkan tingkat pendididikan ayah kategori dasar, menengah dan tinggi dapat dipersentasikan sebagai berikut.

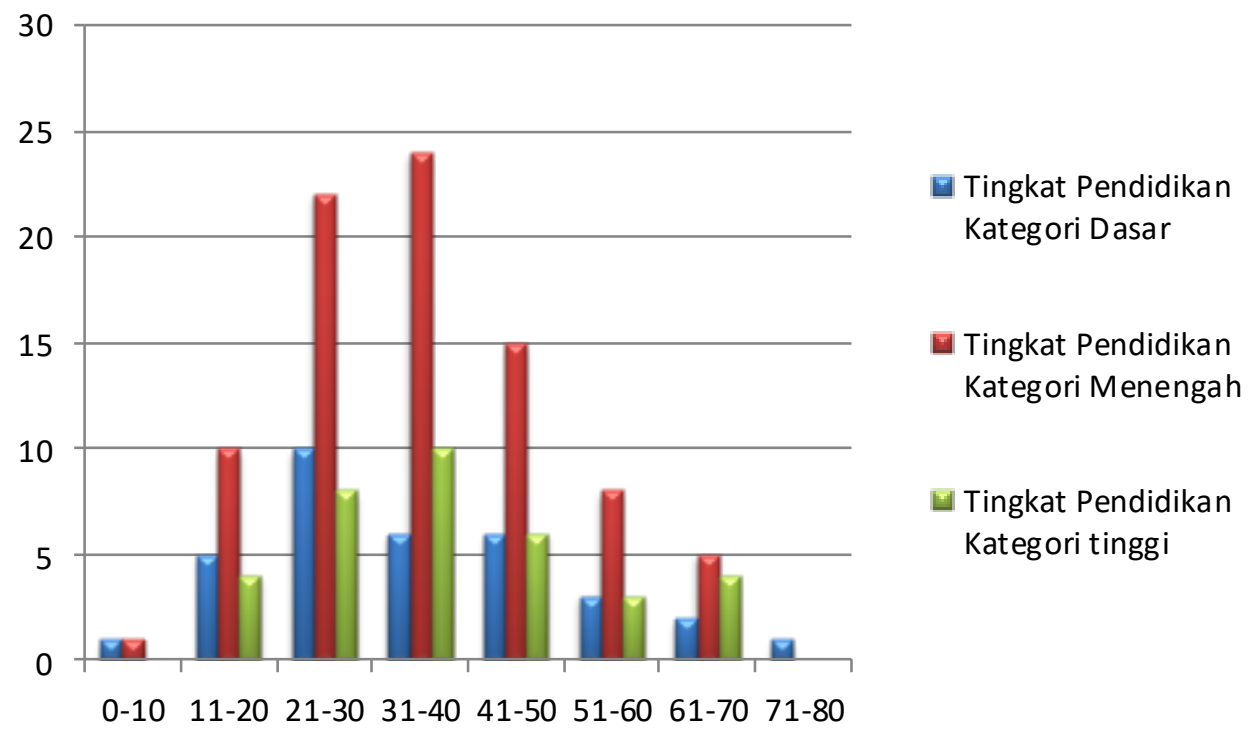

Data hasil belajar matematika siswa berdasarkan tingkat pendidikan ayah kategori dasar diperoleh skor antara 10-72 sebanyak 32 siswa, dengan rata-rata (x) 35.34 ; Median (Me) 33; Modus (Mo) 15; standar deviasi (Sd) 15.9. Data hasil belajar matematika siswa berdasarkan tingkat pendidikan ayah kategori sedang diperoleh skor antara 7-70 sebanyak 87 siswa, dengan rata-rata (x) 35.53; Median (Me) 34; Modus (Mo) 25; standar deviasi (Sd) 13.9. Data hasil belajar matemtika siswa berdasarkan tingkat pendidikan ayah kategori tinggi diperoleh skor antara 1465 sebanyak 35 siswa, dengan rata-rata (x) 37.3; Median (Me) 35; Modus (Mo) 23; standar deviasi (Sd) 14.3.

Sebelum melakukan uji anova satu arah maka perlu dilakukan uji normalitas sebaran dan homogenitas. Uji normalitas ini bertujuan untuk mengetahui apakah variabel berdistribusi normal, mendekati normal atau tidak. Pengujian dilakukan menggunakan uji liliefors dengan taraf signifikasi $\alpha=0.05$

Tabel 3. Hasil Perhitungan Normalitas Tingkat Pendidikan Ayah terhadap Hasil Belajar Matematika Menggunakan SPSS

\begin{tabular}{|c|c|c|c|c|c|c|c|}
\hline \multicolumn{8}{|c|}{ Tests of Normality } \\
\hline & \multirow{2}{*}{$\begin{array}{c}\text { Tingkat } \\
\text { Pendidikan } \\
\text { Orangtua }\end{array}$} & \multicolumn{3}{|c|}{ Kolmogorov-Smirnova } & \multicolumn{3}{|c|}{ Shapiro-Wilk } \\
\hline & & $\begin{array}{c}\text { Statisti } \\
\mathrm{c}\end{array}$ & Df & Sig. & Statistic & $\mathrm{Df}$ & Sig. \\
\hline \multirow[t]{3}{*}{ Hasil belajar } & Dasar & .107 & 32 & $.200^{*}$ & .955 & 32 & .196 \\
\hline & Menengah & .085 & 87 & .165 & .969 & 87 & .035 \\
\hline & Tinggi & .107 & 35 & $.200^{*}$ & .952 & 35 & .133 \\
\hline
\end{tabular}

Berdasarkan pada Tabel 3 di atas pada kolom Kolmorgrof-Smirnov dan Shapiro-Wilk terlihat bahwa nilai sig > $(\alpha=0.05)$. Sehingga untuk uji normalitas diatas menunjukkan bahwa untuk tingkat pendidikan kategori dasar, menengah dan tinggi adalah berdistribusi normal dengan masing masing nilai sig yaitu $0.2,0.35$ dan 0.2

Pada analisis statistik, uji homogenitas bertujuan untuk mengetahui apakah variasi dari beberapa data populasi memiliki variansi yang sama atau tidak. Uji homogenitas yang digunakan adalah metode Barlett. 
Tabel 4. Hasil Uji Homogenitas dengan SPSS

\begin{tabular}{|c|c|c|}
\hline \multicolumn{3}{|c|}{ Test Results } \\
\hline & $\mathrm{M}$ & .890 \\
\hline \multirow{4}{*}{$\mathrm{F}$} & Approx. & .440 \\
\hline & df1 & 2 \\
\hline & $\mathrm{df} 2$ & $3.239 \mathrm{E} 4$ \\
\hline & Sig. & .644 \\
\hline
\end{tabular}

Berdasarkan Tabel 4 di atas diketahui bahwa nilai sig 0.644. Karena nilai sig $0.644>0.05$, maka dapat disimpulkan bahwa varians data hasil belajar matematika siswa dengan tingkat pendidikan orangtua kategori rendah, sedang dan tinggi adalah homogen.. Sehingga asumsi homogenitas dalam uji one way anova terpenuhi.

Setelah memenuhi berbagai uji prasyarat, kemudian dapat dilakukan uji hipotesis dengan menggunakan uji one way anova. Adapun rangkuman hasil perhitungan dapat dilihat pada tabel 5.

Tabel 5. Uji One Way Anova

\begin{tabular}{cccccc}
\hline Sumber Variansi & Jk & Dk & Var & Fhitung & Ftabel \\
\hline Antar Kelompok & 89.08361 & 2 & 44.5418 & 0.21 & 3.06 \\
Dalam Kelompok & 31538.04 & 151 & 208.861 & & \\
Total & 31627.12 & 153 & & & \\
\hline
\end{tabular}

Berdasarkan Tabel 5 dapat dilihat bahwa $\mathrm{F}_{\text {hitung }}=0.21<\mathrm{F}_{\text {tabel }}=\mathrm{l} 3.06$ sehingga dapat disimpulkan bahwa $\mathrm{H}_{0}$ diterima, artinya tidak ada perbedaan hasil belajar matematika siswa berdasarkan tingkat pendidikan ayah kategori dasar, menengah dan tinggi di kelas XI MIPA SMA Negeri 1 Merangin.

Tabel 6. Uji one way anova menggunakan SPSS

\begin{tabular}{llcccc}
\hline \multicolumn{1}{c}{ Hasil Belajar } & $\begin{array}{c}\text { Sum of } \\
\text { Squares }\end{array}$ & Df & $\begin{array}{c}\text { Mean } \\
\text { Square }\end{array}$ & F & Sig. \\
\hline Between groups & 89.084 & 2 & 44.542 & .213 & .808 \\
Within groups & 31538.040 & 151 & 208.861 & & \\
Total & 31627.123 & 153 & & & \\
\hline
\end{tabular}

Pada tabel ringkasan anova satu jalan diatas, diperoleh nilai signifikansi hasil belajar matematika siswa sebesar 0.808 yang berarti lebih besar dari $0.05(0.808>0.05)$. Hal ini berarti $\mathrm{H}_{0}$ diterima, sehingga tidak ada perbedaan hasil belajar matemtika siswa berdasarkan tingkat pendidikan ayah. Dimana antara tingkat pendidikan orangtua kategori dasar, menengah dan tinggi tidak memiliki perbedaan rerata signifikan terhadap hasil belajar matematika siswa di kelas XI MIPA SMA Negeri 1 Merangin. Untuk memperkuat pernyataan tersebut peneliti juga membandingkan nilai $\mathrm{F}_{\text {hitung }}$ dengan $\mathrm{F}_{\text {tabel }}$. Berdasarkan tabel diatas, diketahui nilai $\mathrm{F}_{\text {hitung }}$ sebesar 0.213. kemudian $\mathrm{df}_{1}$ sebesar 2 dan $\mathrm{df}_{2}$ sebesar 151, dapat dilihat pada tabel distribusi $\mathrm{F}$ diperoleh $\mathrm{F}_{\text {tabel }}$ sebesar 3.06. terlihat bahwa $\mathrm{F}_{\text {hitung }}<\mathrm{F}_{\text {tabel }}$, maka tidak ada perbedaan hasil belajar matemtika siswa berdasarkan tingkat pendidikan ayah di kelas XI MIPA SMA Negeri 1 Merangin.

Dari hasil analisis hipotesis diperoleh bahwa tidak terdapat perbedaan hasil belajar matematika siswa berdasarkan tingkat pendidikan ayah Berdasarkan hasil perhitungan yang dilakukan menggunakan one way anova diperoleh nilai signifikansi hasil belajar matematika siswa sebesar 0.808 yang berarti lebih besar dari $\alpha=$ $0.05(0.808>0.05)$ dan $\mathrm{F}_{\text {hitung }}<\mathrm{F}_{\text {tabel }}(0.21<3.06)$ Hal ini mengartikan bahwa $\mathrm{H}_{0}$ diterima,tidak ada ada perbedaan hasil belajar matematika siswa berdasarkan tingkat pendidikan ayah, tingkat pendidikan ayah kategori dasar, menengah dan tinggi di kelas XI MIPA SMA Negeri 1 Merangin.

Hasil penelitian ini mememperkuat teori bahwa ibu merupakan madrasah pertama untuk anaknya sehingga ibu jauh memililiki peranan penting dalam keberhasilan belajar anak. Factor - factor lain yang mempengaruhi hasil belajar matematika siswa bukan hanya latar belakang keluarga seperti ekonomi dan tingkat pendidikan tetapi terdapat faktor lain. Muhibbin syah menjelaskan bahwa factor-factor yang mempengaruhi hasil belajar siswa terbagi menjadi factor internal, factor eksternal dan factor pendekatan belajar: [10]. (a) 
Faktor internal (faktor dari dalam diri siswa), yakni keadaan/ kondisi jasamani dan rohani siswa. Faktor ini meliputi beberapa aspek, yaitu: Aspek fisiologis (yang bersifat jasmaniah) seperti organ-organ khusus siswa contonya tingkat kesehatan mata dan telinga yang sangat berpengaruh dalam kualitas informasi dan pengetahuan yang diperoleh siswaa di kelas; Aspek psikologis (yang bersifat rohaniah) seperti intelegensi, sikap, bakat dan motivasi.. (b) Faktor eksternal (faktor dari luar siswa), yakni kondisi lingkungan disekitar siswa. Factor ini meliputi: Lingkungan sosial, seperti keluarga, guru, masyarakat dan teman; Lingkungan non social, seperti rumah, sekolah, peralatan dan alam. (c) Faktor pendekatan belajar yakni jenis upaya belajar siswa yang meliputi strategi dan metode yang digunakan siswa untuk melakukan kegiatan pembelajaran materi-materi pelajaran. Factor ini meliputi: Pendekatan tinggi, seperti speculative, achieving; Pendekatan sedang, seperti analytical, deep; Pendekatan rendah, seperti reproductive, surface

Berdasarkan masalah pada penelitian ini, melalui observasi dan wawancara peneliti menemukan jawaban kontradiktif antara teori dan penemuan dilapangan bahwa tidak berpengaruhnya tingkat pendidikan Ayah terhadap hasil belajar siswa diantaranya yaitu system pembelajaran yang berubah-ubah dari pembelajaran tatap muka menjadi system pembelajaran online dan kembali berubah menjadi metode shift. Hal ini menimbulkan ketidaknyamanan dan ketidaksiapan dari berbagai pihak yaitu tenaga pendidik (guru), siswa dan juga orangtua.

Guru menyampaikan bahwa selama pembelajaran online terjadinya keterbatasan guru dalam penyampaian materi sehingga siswa hanya diberikan banyak tugas untuk berlatih mandiri dirumah. Saat mulai pembelajaran tatap muka dengan metode shift, guru harus mengejar ketinggalan materi dengan jam pelajaran yang terbatas, terkadang hal tersebut membuat guru kewalahan. Begitu pula pada siswa, siswa mengalami kebingungan dan ketidak mampuan dalam memahami materi dan menyelesaikan tugas dimana siswa dituntut untuk belajar mandiri, sehingga terjadinya kejenuhan dalam belajar. Siswa beranggapan bahwa matematika merupakan mata pelajaran yang terbilang sulit sehingga sangat dibutuhkan dampingan dan bimbingan dari guru dan orangtua.

Peran orangtua dalam pembelajaran online ini seharusnya dapat memperlihatkan kontribusi orangtua (ayah) dalam mendidik anak namun pada faktanya orangtua kurang meningkatkan perannya sebagai provider, teacher, dan problem solving. Dimana orangtua hanya memfasilitasi handphone dan paket internet sebagai media pembelajaran namun untuk menjadi teacher di keluarga terjadinya ketidakmampuan orangtua, mulai dari kesibukkan orangtua bekerja, materi pembelajaran SMA yang juga dianggap sulit oleh orangtua karena sudah lupa, namun sayangnya dorongan orangtua untuk menfasilitasi anak untuk mengikuti bimbingan belajar pun kurang dengan berbagai alasan seperti keterbatasan ekonomi.

\section{Kesimpulan}

Berdasarkan hasil analisis penelitian mengenai perbedaan hasil belajar matematika siswa berdasarkan tingkat pendidikan ayah di kelas XI MIPA SMA Negeri 1 Merangin pada tahun pelajaran 2020/2021, diperoleh hasil akhir bahwa tidak terdapat perbedaan hasil belajar matematika siswa berdasarkan tingkat pendidikan ayah di kelas XI MIPA SMA Negeri 1 Merangin pada tahun pelajaran 2020/2021. Berdasarkan hasil perhitungan yang dilakukan menggunakan uji one way anova diperoleh nilai signifikansi hasil belajar matematika siswa sebesar 0.808 yang berarti lebih besar dari $\alpha=0.05(0.808>0.05)$ dan $\mathrm{F}_{\text {hitung }}<\mathrm{F}_{\text {tabel }}(0.21<3.06)$. Hal ini mengartikan bahwa $\mathrm{H}_{0}$ diterima, sehingga tidak terdapat perbedaan hasil belajar matematika siswa berdasarkan tingkat pendidikan ayah.

Berdasarkan pembahasan dan simpulan, maka peneliti dapat menyarankan kepada pihak pihak yang memiliki kewajiban dan bertanggung jawab terhadap anak/ siswa, yaitu: Orangtua hendaknya dapat meningkatkan potensi diri mengingat bahwa perkembanagan zaman yang menuntut orangtua dapat membimbing anak dalam belajar dirumah. Orangtua pun sebaiknya memberikan fasilitas belajar, baik itu materil maupun non 
materil agar anak dapat meningkatkan hasil belajar. Guru hendaknya memberikan fasilitas belajar yang memadai kepada siswa dan memberikan metode belajar yang menyenangkan dan dapat disesuaikan dengan situasi dan kondisi pendemi saat ini guna dapat meningkatkan hasil belajara siswa. Penelitian ini sangat terbatas, baik dari segi jumlah variable dan populasinya sehingga diharapkan peneliti yang lain dapat melengkapi penetian sebelumnya dan penelitian ini menginformasikan bahwa tingkat pendidikan orangtua tidak memberikan pengaruh signifikan terjadap hasil belajar.

\section{Daftar Pustaka}

[1] M. Mustari, D. Ph, M. T. Rahman, and D. Ph, Manajemen Pendidikan. Jakarta: RajaGrafika Persada, 2014.

[2] A. Nasrun, "56878-ID-psikologi-belajar," Al-Fikrah J. Kependidikan Islam IAIN Sulthan Thaha Saifuddin, p. 177, 2015.

[3] KOMPRI, Belajar, Faktor-Faktor Yang Mempengaruhinya. Yogyakarta: Media Akademi, 2017.

[4] Oemar Hamalik, Proses Belajar Mengajar. Jakarta: Bumi Aksara, 2007.

[5] R. Setya, Dasar-Dasar Kependidikan. Jakarta: Rama Edukasitama, 2013.

[6] S. Junita, A. Rahmi, and H. Fitri, "Pengaruh Motivasi Belajar dan Perhatian Orangtua terhadap Hasil Belajar Matematika Siswa Kelas VII SMP Negeri 1 Baso Tahun Pelajaran 2018/2019," JURING (Journal Res. Math. Learn., vol. 2, no. 1, p. 088, 2019, doi: 10.24014/juring.v2i1.6879.

[7] V. Saswita, Isnaniah, and R. K. Sari, "Pengaruh Strategi Pembelajaran Giving Question and Getting Answer ( GQGA) terhadap Hasil Belajar Matematika," Juring (Journal Reasearch Math. Learn., vol. 2, no. 2, pp. 112-119, 2019.

[8] E. Suherman, Strategi Pembelajaran Matematika Kontemporer. Bandung: JICA-Universitas Pendidikan Indonesia (UPI), 2001.

[9] S. H. Nur, Starategi Pembelajaran Matematika. Yogyakarta: Matematika, 2017.

[10] Muhibin Syah, Psikologi Belajar. Jakarta: PT. Raja Grafindo, 2011.

[11] A. Rinja, "Pengaruh Tingkat Pendidikan Orangtua Dan Minat Belajar Terhadap Prestasi Belajar Sejarah Siswa Kelas XI SMKN 2 Depok Yogyakarta Tahuan Ajaran 2015-2016,” p. 149, 2017.

[12] Zahara Idris, Dasar-Dasar Pendidikan, 2nd ed. Padang: Angkasa Raya, 1995.

[13] P. Bahasa, Kamus Besar Bahasa Indonesia. Balai Pustaka.

[14] Sudjana, Metode Statistik. Bandung: PT. Tarsito, 1992.

[15] Yulingga Nanda dan Wasis Himawanto., Statistika Pendidikan. Yogyakarta: Deeppublish, 2017.

[16] Syofian Siregar, Statistic Parametric Untuk Penelitian Kuantitatif dilengkai dengan perhitungan manual dan aplikasi SPSS versi 17. Jakarta: Bumi Aksara, 2014.

[17] Agus Widodo dan Kwardiniya Andawaningtyas, Pengantar Statistik. Malang: UB Press, 2017. 